\title{
Cross-slope variations of dissolved organic carbon in the Gulf of Cadiz, NE Atlantic Ocean (February 1998)
}

\author{
Evgeny V. Dafner ${ }^{1}$, Richard Sempéré ${ }^{1, *}$, Nicolás González ${ }^{2}$, Fernando Gomez ${ }^{3}$, Madeleine Goutx ${ }^{1}$ \\ ${ }^{1}$ Laboratoire de Microbiologie marine, CNRS/INSU EP2032, Université de la Méditerranée, Campus de Luminy, Case 907, \\ 13288 Marseille Cedex 9, France \\ ${ }^{2}$ Instituto Español de Oceanografia (IEO), Muelle de Animas s/n, 15001 La Coruña, Spain \\ ${ }^{3}$ Area de Ecología, Facultad de Ciencias del Mar, Universidad de Cádiz, 11510 Puerto Real (Cádiz), Spain
}

\begin{abstract}
Our observations at a traverse of Cadiz in February 1998 indicated dissolved organic carbon (DOC) concentrations ranging from 61 to $89 \mu \mathrm{M} \mathrm{C}$ within the Spanish Shelf Water, from 48 to $64 \mu \mathrm{MC}$ within the North Atlantic Surface Water, and from 49 to $55 \mu \mathrm{MC}$ within the North Atlantic Central Water. Moreover, according to temperature and salinity data, the shallow core of the Mediterranean outflow was also identified deeper than $350 \mathrm{~m}$ depth with DOC concentrations between 52 and $58 \mu \mathrm{M} C$. The data suggest that DOC distribution at the traverse of the Gulf of Cadiz was controlled by outputs of degraded particles transported within alongslope descending shelf waters and also by features of the circulation in the Gulf of Cadiz. An estimate of organic carbon transport suggests that ca 1.34 to $2.68 \times 10^{2} \mathrm{~mol} \mathrm{C} \mathrm{s}^{-1}$ were transported within the shallow core of Mediterranean outflow. This amount of DOC was 2 orders of magnitude less than that calculated within the Mediterranean outflow in the Strait of Gibraltar for the summer and autumn seasons. These processes might partly regulate the biogeochemistry of the shallow core of the Mediterranean outflow along the Iberian coast.
\end{abstract}

KEY WORDS: DOC - Transport - Shallow core of Mediterranean outflow · Gulf of Cadiz - NE Atlantic Ocean

Previous investigations have emphasised the importance of the Gulf of Cadiz surface waters in the transport of nutrients (Cano 1978, Minas \& Minas 1993), trace metals (Van Geen et al. 1991, Morley et al. 1997) mesozooplankton and ichthyoplankton (Greze et al. 1985, Rubin et al. 1997) to the Western Mediterranean Sea through the Strait of Gibraltar. More recently, we found that the high productivity of waters along the Iberian Coast and the continental shelf of the Gulf of Cadiz was likely the ecological source of the high con-

- Addressee for correspondence.

E-mail: sempere@luminy.univ-mrs.fr centrations (>100 $\mu \mathrm{M} \mathrm{C}$ ) of dissolved organic carbon (DOC) observed in the Atlantic inflow in the northwestern part of the Strait of Gibraltar in summer and in autumn (Anonymous 1998).

By contrast, little is known about the organic carbon content of the deep-water masses in the Gulf of Cadiz and its possible export toward adjacent seas. The high density Mediterranean outflow leaves the Strait and flows around the northern side of the Gulf of Cadiz in contact with the bottom before reaching its compensating level at ca $1200 \mathrm{~m}$ depth and spreading throughout the North Atlantic Ocean (Stanton 1983). It has now been documented that heavy erosion in the Gulf of Cadiz causes advection and resuspension of sediments from the continental slope (Eittreim et al. 1976). As intensive biological production occurs in coastal areas such as the Gulf of Cadiz, part of this production might be exported as continental shelf phytodetritus (Walsh 1991). Although these processes are likely to be potential sources of organic carbon inputs within the Mediterranean outflow, there are currently no reports dealing with organic carbon observations in the Gulf of Cadiz. In the present paper, we describe the distribution of the DOC pool in the Gulf of Cadiz during winter and we give an estimation of its transport to the north-west from the Strait of Gibraltar through a shallow core of Mediterranean outflow found in the investigated area.

Materials and methods. The seawater samples were taken from the RV 'Cornide de Saavedra' with a CTD rosette system equipped with 10 l Niskin bottles between 10 and 11 February 1998 at 5 stations along a section in the Gulf of Cadiz (Fig. 1). Samples for DOC analysis were withdrawn from Niskin bottles into precombusted $\left(450^{\circ} \mathrm{C}, 6 \mathrm{~h}\right) 0.5 \mathrm{l}$ glass flasks (Schott $\left.{ }^{\oplus}\right)$. They were filtered through precombusted $\left(450^{\circ} \mathrm{C}, 6 \mathrm{~h}\right) \mathrm{GF} / \mathrm{F}$ 


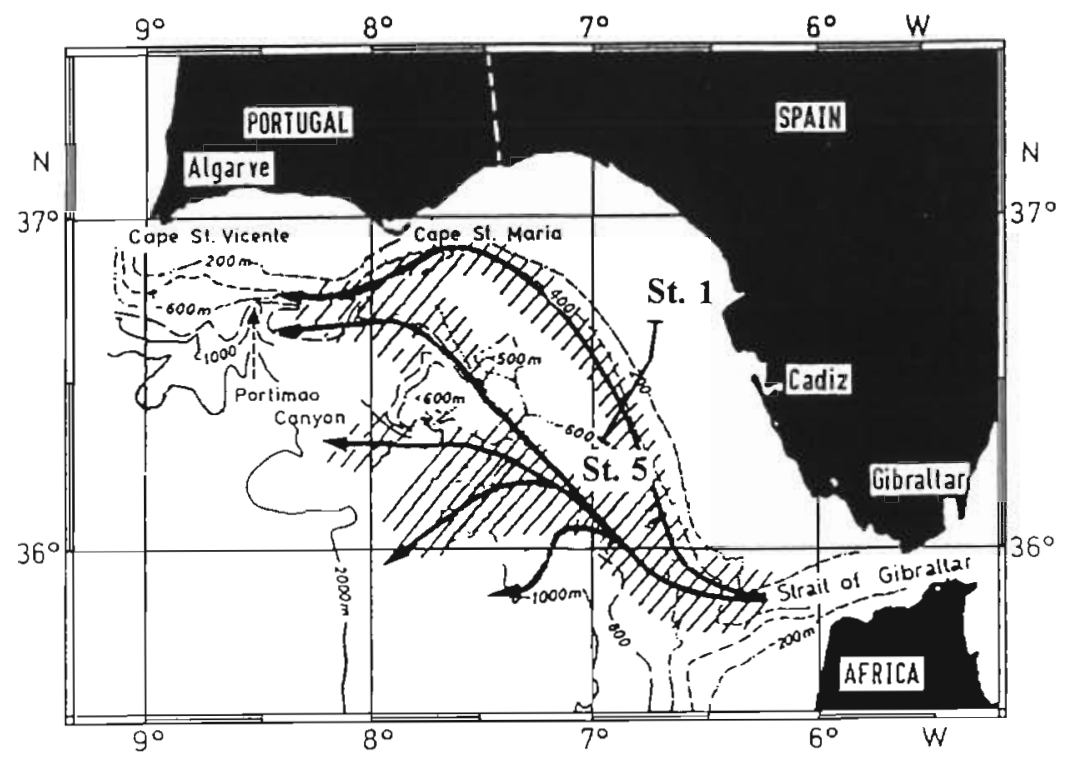

glass fibre filters, collected in duplicate in $10 \mathrm{ml}$ precombusted glass ampoules, poisoned by addition of $\mathrm{HgCl}_{2}\left(10 \mathrm{mg} \mathrm{l}^{-1}\right.$ final conc.), sealed, and stored in the dark. Samples were analysed by using a commercially available Shimadzu TOC -5000 analyser according to the method described in Yoro et al. (1997). The filtration

Fig. 1. Bathymetry of the Gulf of Cadiz and veins of Mediterranean outflow (hatched areas) in the Gulf of Cadiz; flow separation is directly controlled by the local bottom topography with its numerous canyons, after Käse \& Zenk (1996). The hydrographic section sampled during cruise of the RV 'Cornide de Saavedra' $(10-11$ February, 1998) is shown by the line Stn 1-Stn 5

Table 1. The 5 stations sampled at the traverse of Cadiz with depth of station $(Z, m)$, latitude $(N)$ and longitude (W), nominal depths of sampling and values of temperature, salinity, DOC, POC, PON, POC/PON ratio, and phaeo and phaeo/chl a ratio

\begin{tabular}{|c|c|c|c|c|c|c|c|c|c|c|}
\hline Station & Position & $\begin{array}{c}\text { Depth } \\
\text { (m) }\end{array}$ & $\begin{array}{c}\mathrm{T} \\
\left({ }^{\circ} \mathrm{C}\right)\end{array}$ & $\begin{array}{c}S \\
\{\% 0\}\end{array}$ & $\begin{array}{l}\text { DOC } \\
(\mu M)\end{array}$ & $\begin{array}{l}\text { POC } \\
(\mu M)\end{array}$ & $\begin{array}{l}\text { PON } \\
(\mu M)\end{array}$ & $\mathrm{POC} / \mathrm{PON}$ & $\begin{array}{l}\text { phaeo } \\
\left(\mu \mathrm{g} \mathrm{l}^{-1}\right)\end{array}$ & $\begin{array}{c}\text { phaeo/ } \\
\text { chl a }\end{array}$ \\
\hline $\begin{array}{l}\text { Stn } 1 \\
\text { Lat. } \\
\text { Long. } \\
Z \text { (m) }\end{array}$ & $\begin{array}{c}36^{\circ} 40^{\circ} 09^{\prime \prime} \\
06^{\circ} 41^{\prime} 00^{\prime \prime} \\
53\end{array}$ & $\begin{array}{r}7 \\
10 \\
20 \\
29 \\
42\end{array}$ & $\begin{array}{l}16.14 \\
16.14 \\
16.14 \\
16.14 \\
16.14\end{array}$ & $\begin{array}{l}36.06 \\
36.09 \\
36.11 \\
36.11 \\
36.15\end{array}$ & $\begin{array}{l}61 \\
89 \\
64 \\
65 \\
64\end{array}$ & $\begin{array}{l}19 \\
21 \\
21 \\
22\end{array}$ & $\begin{array}{l}1.4 \\
1.6 \\
1.6 \\
1.6\end{array}$ & $\begin{array}{l}13.6 \\
13.1 \\
13.1 \\
13.8\end{array}$ & $\begin{array}{l}0.808 \\
0.848 \\
1.069 \\
1.122 \\
0.888\end{array}$ & $\begin{array}{l}1.6 \\
1.6 \\
2.3 \\
2.5 \\
1.6\end{array}$ \\
\hline $\begin{array}{l}\text { Stn } 2 \\
\text { Lat. } \\
\text { Long. } \\
Z(\mathrm{~m})\end{array}$ & $\begin{array}{c}36^{\circ} 34^{\prime} 35^{\prime \prime} \\
06^{\circ} 45^{\prime} 05^{\prime \prime} \\
107\end{array}$ & $\begin{array}{r}14 \\
23 \\
30 \\
48 \\
75 \\
100\end{array}$ & $\begin{array}{l}17.11 \\
17.11 \\
17.12 \\
17.12 \\
17.12 \\
17.12\end{array}$ & $\begin{array}{l}36.47 \\
36.46 \\
36.46 \\
36.46 \\
36.46 \\
36.46\end{array}$ & $\begin{array}{l}63 \\
64 \\
63 \\
\\
64 \\
63\end{array}$ & $\begin{array}{l}3 \\
5 \\
4 \\
4\end{array}$ & $\begin{array}{l}0.4 \\
0.9 \\
\\
0.8 \\
0.8\end{array}$ & $\begin{array}{l}7.5 \\
5.6 \\
\\
5.0 \\
5.0\end{array}$ & $\begin{array}{l}0.317 \\
0.311 \\
0.317 \\
0.423 \\
0.342 \\
0.348\end{array}$ & $\begin{array}{l}0.7 \\
0.7 \\
0.7 \\
1.0 \\
0.7 \\
0.7\end{array}$ \\
\hline $\begin{array}{l}\text { Stn } 3 \\
\text { Lat. } \\
\text { Long. } \\
Z(\mathrm{~m})\end{array}$ & $\begin{array}{c}36^{\circ} 29^{\prime} 12^{\prime \prime} \\
06^{\circ} 49^{\prime} 51^{\prime \prime} \\
360\end{array}$ & $\begin{array}{r}9 \\
23 \\
48 \\
101 \\
172 \\
200 \\
250 \\
301 \\
322 \\
352\end{array}$ & $\begin{array}{l}17.09 \\
17.09 \\
17.10 \\
17.11 \\
16.72 \\
16.30 \\
15.97 \\
15.58 \\
15.28 \\
15.40\end{array}$ & $\begin{array}{l}36.47 \\
36.47 \\
36.47 \\
36.47 \\
36.43 \\
36.43 \\
36.59 \\
36.75 \\
36.79 \\
36.88\end{array}$ & $\begin{array}{l}48 \\
48 \\
54 \\
55 \\
53 \\
58 \\
65 \\
62 \\
55 \\
58\end{array}$ & $\begin{array}{l}4 \\
4 \\
5\end{array}$ & $\begin{array}{l}0.5 \\
0.6 \\
0.8 \\
\\
\\
0.7\end{array}$ & $\begin{array}{l}8.0 \\
6.7 \\
6.3 \\
\\
7.1\end{array}$ & $\begin{array}{l}0.109 \\
0.086 \\
0.073 \\
0.111 \\
0.152 \\
0.076 \\
0.067 \\
0.064 \\
0.066 \\
0.087\end{array}$ & $\begin{array}{l}0.2 \\
0.2 \\
0.2 \\
0.3 \\
0.9 \\
1.5 \\
1.6 \\
1.3 \\
1.3 \\
1.7\end{array}$ \\
\hline $\begin{array}{l}\text { Stn } 4 \\
\text { Lat. } \\
\text { Long. } \\
Z(\mathrm{~m})\end{array}$ & $\begin{array}{c}36^{\circ} 24^{\prime} 25^{\prime \prime} \\
06^{\circ} 54^{\prime} 13^{\prime \prime} \\
464\end{array}$ & $\begin{array}{r}20 \\
54 \\
105 \\
162 \\
252 \\
297 \\
364 \\
382 \\
451\end{array}$ & $\begin{array}{l}17.12 \\
17.12 \\
17.11 \\
16.61 \\
13.79 \\
13.34 \\
14.12 \\
14.29 \\
15.07\end{array}$ & $\begin{array}{l}36.47 \\
36.47 \\
36.47 \\
36.38 \\
35.92 \\
35.87 \\
36.48 \\
36.57 \\
37.05\end{array}$ & $\begin{array}{l}61 \\
60 \\
57 \\
54 \\
49 \\
49 \\
49 \\
57 \\
52\end{array}$ & $\begin{array}{l}7 \\
8 \\
6 \\
7\end{array}$ & $\begin{array}{l}0.4 \\
\\
0.4 \\
0.4 \\
0.4\end{array}$ & $\begin{array}{l}17.5 \\
\\
20.0 \\
15.0 \\
17.5\end{array}$ & $\begin{array}{l}0.222 \\
0.253 \\
0.209 \\
0.072 \\
0.022 \\
0.019 \\
0.042 \\
0.044 \\
0.076\end{array}$ & $\begin{array}{l}0.6 \\
0.7 \\
0.7 \\
1.8 \\
0 \\
0 \\
1.6 \\
1.9 \\
0\end{array}$ \\
\hline $\begin{array}{l}\text { Stn } 5 \\
\text { Lat. } \\
\text { Long. } \\
Z(\mathrm{~m})\end{array}$ & $\begin{array}{c}36^{\circ} 24^{\prime} 45^{\prime \prime} \\
06^{\circ} 57^{\prime} 03^{\prime \prime} \\
433\end{array}$ & $\begin{array}{r}53 \\
105 \\
134 \\
151 \\
202 \\
253 \\
300 \\
333 \\
365\end{array}$ & $\begin{array}{l}17.12 \\
17.11 \\
17.08 \\
16.78 \\
15.00 \\
13.79 \\
13.36 \\
13.02 \\
14.14\end{array}$ & $\begin{array}{c}36.47 \\
36.47 \\
36.46 \\
36.41 \\
36.12 \\
35.91 \\
35.87 \\
35.9 \\
36.49\end{array}$ & $\begin{array}{l}62 \\
64 \\
64 \\
61 \\
65 \\
54 \\
55 \\
53 \\
53\end{array}$ & $\begin{array}{l}3 \\
3 \\
3\end{array}$ & $\begin{array}{l}0.5 \\
0.3 \\
0.2 \\
0.2\end{array}$ & $\begin{array}{l}10.0 \\
10.0 \\
15.0 \\
15.0\end{array}$ & $\begin{array}{l}0.068 \\
0.051 \\
0.022 \\
0.012 \\
0.006 \\
0.004 \\
0.005 \\
0.003 \\
0.007\end{array}$ & $\begin{array}{l}0.1 \\
0.1 \\
0.2 \\
0.4 \\
1.0 \\
0.8 \\
0.6 \\
1.5 \\
0\end{array}$ \\
\hline
\end{tabular}


blank, which included blanks of the filter and glass filtration system, was estimated to $5 \mu \mathrm{M} \mathrm{C}$ by filtering

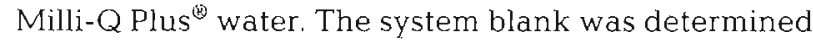
by analysing low carbon water from ampoules provided by J. H. Sharp (ca $5 \mu \mathrm{M}$ C). This value was subtracted from all measured values. DOC contamination from the preservation reagent and from the phosphoric acid was below the detection limit. Ogawa \& Ogura (1992) did not find significant changes in DOC concentrations between fresh samples and those preserved with $\mathrm{HgCl}_{2}$ for about 3 mo. Intercalibration exercises in 1995 organised by $\mathrm{J}$. $H$. Sharp indicated that our instrument was suitable for marine DOC studies.

Some samples for particulate organic carbon and nitrogen (POC and PON) analyses were collected after filtration of $2 \mathrm{l}$ of seawater on precombusted $\left(450^{\circ} \mathrm{C}, 6 \mathrm{~h}\right) \mathrm{GF} / \mathrm{F}$ filters, which were dried on silica gel and frozen to $-20^{\circ} \mathrm{C}$ until analysis in the laboratory. Measurements were carried out with a Perkin Elmer 2400 CHN analyser. To measure phytopigments, 0.51 of seawater were filtered through GF/F filters at low pressure $(<100 \mathrm{~mm} \mathrm{Hg})$. Pigments were extracted in $90 \%$ acetone for $24 \mathrm{~h}$ in cold and dark conditions. After this time, chlorophyll a (chl a) was estimated fluorimetrically by using a Turner Design-10 fluorimeter calibrated with pure chl a (Sigma Co.) (UNESCO 1994). All data are presented in Table 1.

Results and discussion. DOC content in the different water bodies: Physical parameters including temperature and salinity (Fig. 2) indicate a homogeneous water body from the surface to the bottom in the upper slope and down to $135 \mathrm{~m}$ offshore $\left(\mathrm{T}=16.14\right.$ to $17.12^{\circ} \mathrm{C}, \mathrm{S}=$ 36.06 to $36.47 \%$ ). At $\operatorname{Stn} 1$, salinity values lower than 36.10 characterised the Spanish shelf water (Van Geen et al. 1988, 1991) with the highest DOC value ( $89 \mu \mathrm{M} \mathrm{C}$, Table 1, Fig. 3). The salinity values higher than 36.10 very likely correspond to those of the North Atlantic Surface Water (NASW). As shown in Fig. 3, the DOC concentrations within the NASW ranged from $64 \mu \mathrm{M} \mathrm{C}$ inshore down to $48 \mu \mathrm{M} \mathrm{C}$ in the middle of the section (Stn 3). The North Atlantic Central Water (NACW) was found between 250 and $400 \mathrm{~m}$ depth (Fig. 2) and was defined by minima of both salinity $(<36.00 \%$ ) and temperature $\left(<13.80^{\circ} \mathrm{C}\right)$. The colder and less saline NACW overlays the Mediterranean outflow and underlays NASW, producing thermohaline and DOC gradients. NACW contained the lowest DOC concentrations, with nearly homogeneous values in the range of 48 to $49 \mu \mathrm{M} \mathrm{C}$. Doval et al. (1997), with reference to unpub- lished data by Alvarez-Salgado \& Miller, have reported that DOC concentrations in the East NACW (300 to $400 \mathrm{~m}$ ) were about $60 \mu \mathrm{M} \mathrm{C}$. A previous investigation in the north-western part of the Strait of Gibraltar has shown that in the modified NACW (S = 36.05\%, depth $158 \mathrm{~m}$ ) the total organic carbon (TOC) concentration was $76 \mu \mathrm{M} \mathrm{C}$ during the productive summer period (Anonymous 1998).

At Stn 4, we observed the well-known high temperature - high salinity layer at the bottom associated with the Mediterranean outflow $\left(15.30^{\circ} \mathrm{C}\right.$ and $37.07 \%$ ). The bottom contour in Fig. 2 suggests that this section was
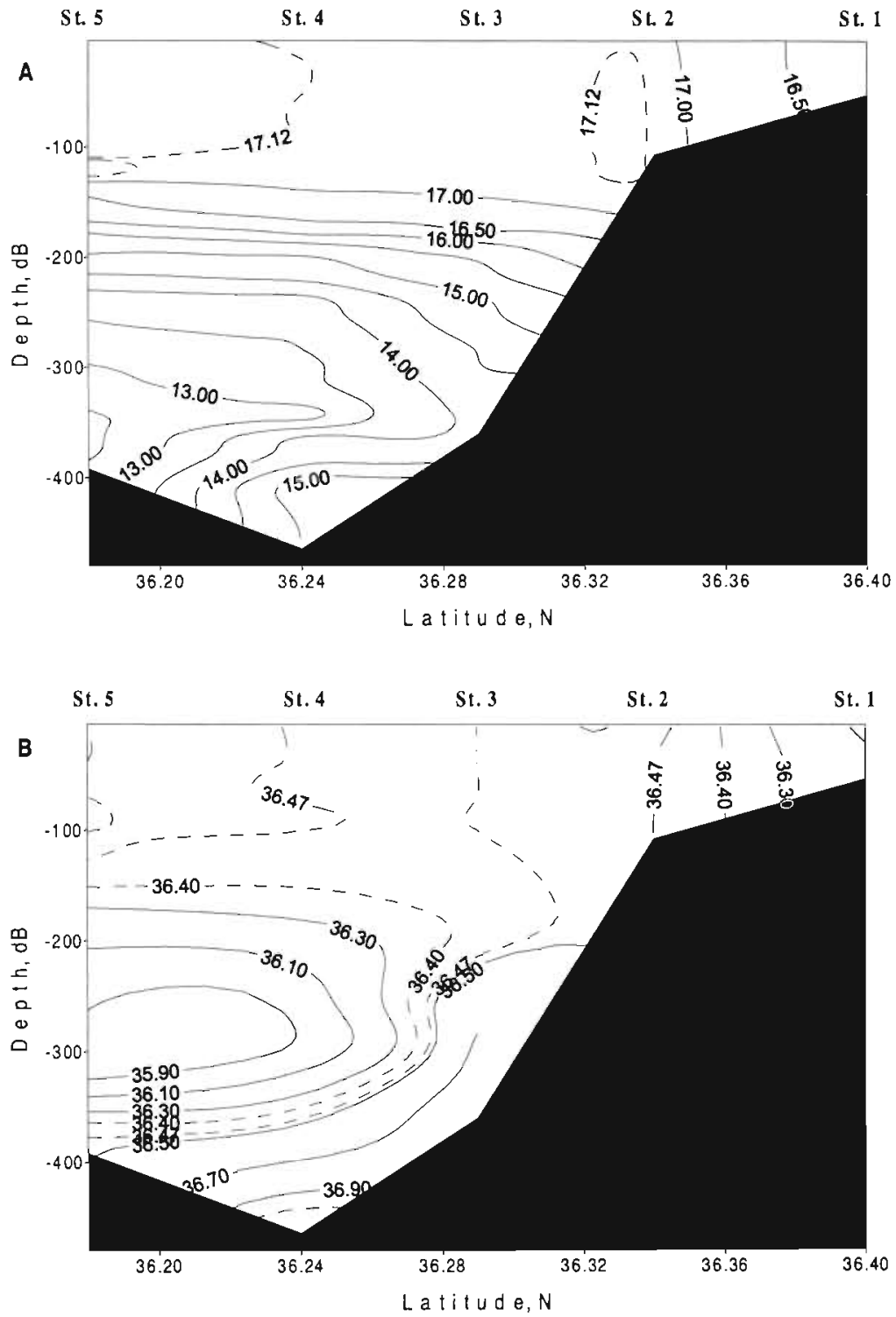

Fig. 2. Cross-slope distributions of $(A)$ temperature $\left({ }^{\circ} \mathrm{C}\right)$ and $(B)$ salinity (\%) along the section at the traverse of Cadiz (10-11 February 1998, Gulf of Cadiz). Note that the bottom represents the depth observed at each station and is not a typical along-slope bathymetric profile 


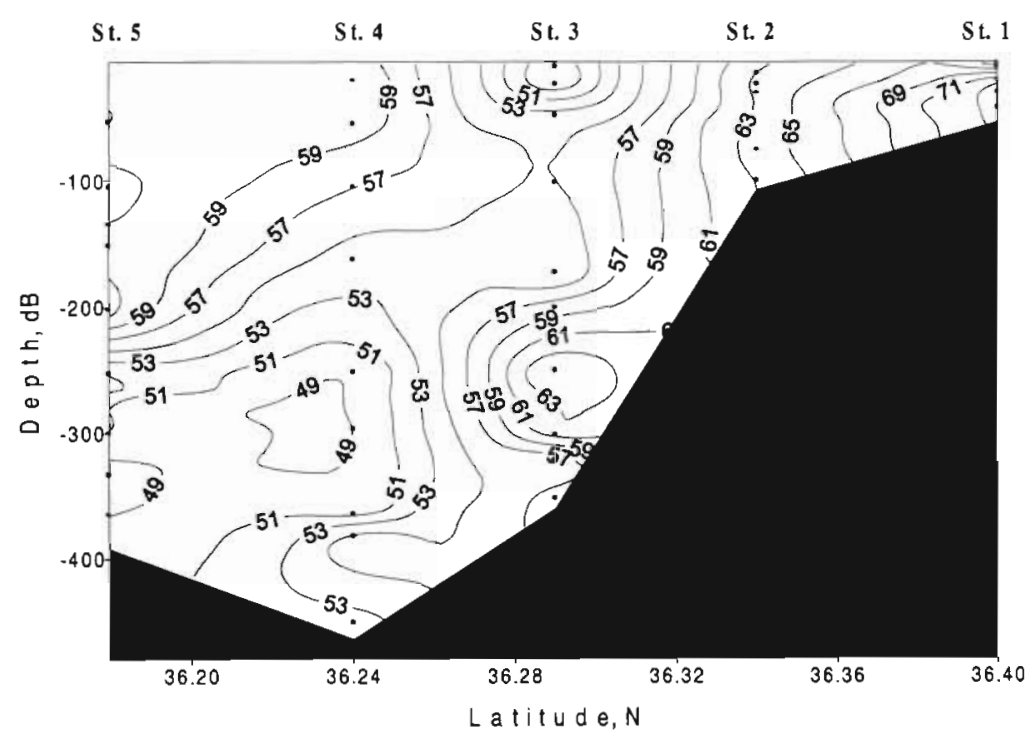

Fig. 3. Cross-slope distributions of DOC $(\mu \mathrm{MC})$ along the section at the traverse of Cadiz (10-11 February 1998, Gulf of Cadiz)

along-slope descending of water. In a study of the thermohaline structure in the area close to the San Vincent Cap, Ambar et al. (1976) found the presence of water of shallow origin at between 450 and $580 \mathrm{~m}$ depth and hypothesised that the observed anomalous thermohaline characteristics were due to winter cooling and consequent sinking of this water from the shelf.

In addition, Fig. 4B displays the distribution of computed geostrophic velocities and explains several features of organic carbon distribution, with the most evident feature at the slope (ca $250 \mathrm{~m}$ ). Computed velocities are relatively high compared to those observed previously in the Gulf of Cadiz (Madelaine 1970, Zenk 1975, Ambar \& Howe 1979b, among others). Interestingly, we observed that the maximum velocity value $\left(-16 \mathrm{~cm} \mathrm{~s}^{-1}\right.$; around $250 \mathrm{~m}$ at Stn 3) was associated with high DOC concentration (65 $\mu \mathrm{M} \mathrm{C}$, Fig, 3). This suggests that

made above a valley, and temperature and salinity distributions show that the Mediterranean outflow spreads along the bottom and the continental slope. Ambar \& Howe $(1979 a$, b) have observed in this area the separation of the Mediterranean outflow in 2 - upper and lower-cores. In the Gulf of Cadiz area and off the southern half of the western coast of Portugal, Ambar (1983) has described a third core, the shallow core, which spreads between 400 and $700 \mathrm{~m}$ depth. Distributions of temperature and salinity obtained from the CTD profile (Fig. 2), as well as density ( 27.25 to $27.45 \mathrm{~kg} \mathrm{~m}^{-3}$, figure not shown), suggest that we have observed the shallow core of Mediterranean outflow, where DOC concentrations amounted to $52-58 \mu \mathrm{M} \mathrm{C}$. These concentrations were similar to the near-bottom TOC value $(58 \mu \mathrm{M} \mathrm{C})$ we measured in June 1997 in the Mediterranean outflow above the Spartell sill, and lower than those (62 to $68 \mu \mathrm{M} \mathrm{C}$ ) we observed in the near bottom waters in the Tarifa Narrows in September 1997 (Anonymous 1998).

Physical evidence of shelf waters descending: An additional feature in this section is the existence of an along-slope DOC gradient which suggests the alongslope export of organic material likely related to winter convection. To prove its existence and to explain some additional features of DOC distribution at the traverse of Cadiz we have examined the nature of the physical environment with regard to the density (figure not shown), density gradient, which may be interpreted as a buoyancy frequency (Fig. 4A), and geostrophic velocity (Fig. 4B). The curvature of Brunt-Väisälä frequencies near the slope between 150 to $250 \mathrm{~m}$ (Fig. 4A, isolines $1.5,2.0$ and 2.5 cycles $[c] \mathrm{h}^{-1}$ ) suggests the this DOC accumulation within this undercurrent was due to hydrodynamic concentrations of along-slope descending material, particle resuspension and subsequent breakdown (see next section). A similar hypothesis was presented by Milliman (1994), who assumed that the Gulf Stream and/or storm events in the Cape Fear and Cape Hatteras areas may induce resuspension of sediment and organic matter from the shelf and transport it offshore.

Potential sources of DOC along the Gulf of Cadiz transect: Particle fragmentation and dissolution might be a significant source of DOC in estuarine (Sempéré et al. 1994, Sempéré \& Cauwet 1995) marine environments (Smith et al. 1992). Thus, sources for DOC in the Gulf of Cadiz may be sought from the distribution of suspended matter and its origin along the transect. During filtration of shelf water samples for DOC analysis at Stn 1, filters had a distinct green-brown colour, suggesting a large amount of suspended material in those waters. As for DOC, concentrations of POC and PON (Table 1) throughout the water column at this station were almost homogeneous (19 to $22 \mu \mathrm{M} \mathrm{C}$ and 1.4 to $1.6 \mu \mathrm{M} N$ respectively). The $\mathrm{POC} / \mathrm{PON}$ ratio was higher than 10, showing that one source for this suspended material probably derives from river outputs through the shelf (Parsons et al. 1977). Only at Stns 2 and 3 were the POC/PON values $(5.7$ to 8.0 ) close to the classical Redfield ratio of 6.6 , indicating a major contribution of organic matter from plankton, faecal pellets and other compounds of biological origin easily degradable with a high nutritive value (Buscail et al. 1990). At the other stations, $\mathrm{C} / \mathrm{N}$ ratios were as much as or more than 2 - or 3 -fold the Redfield values, suggest- 


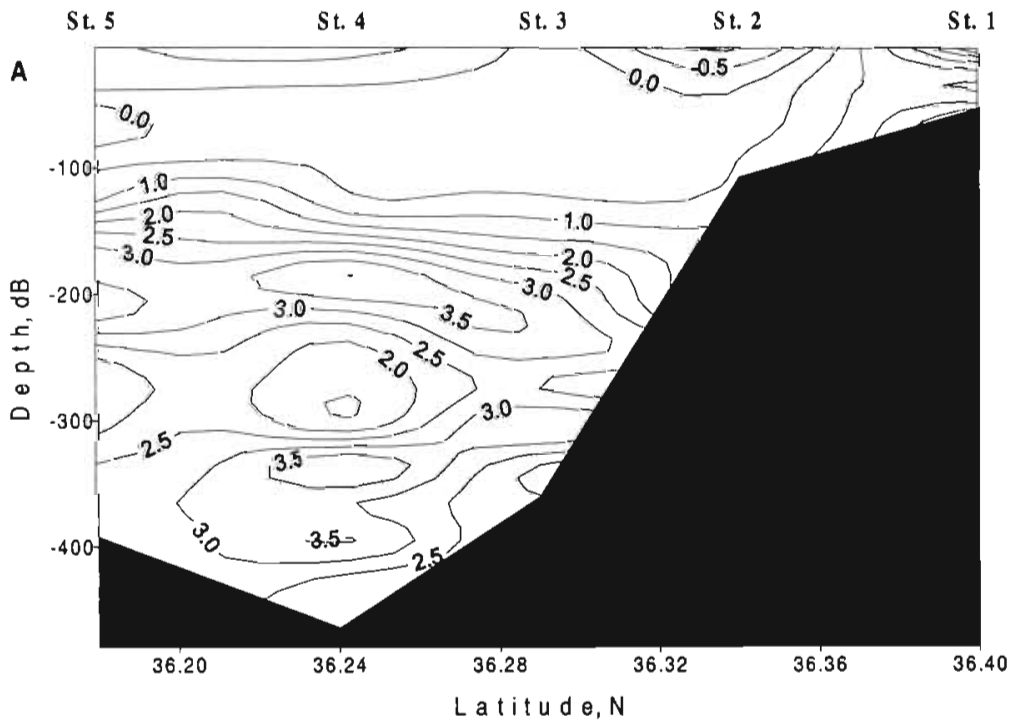

St. 5 St. 4 St. 3 St. 2

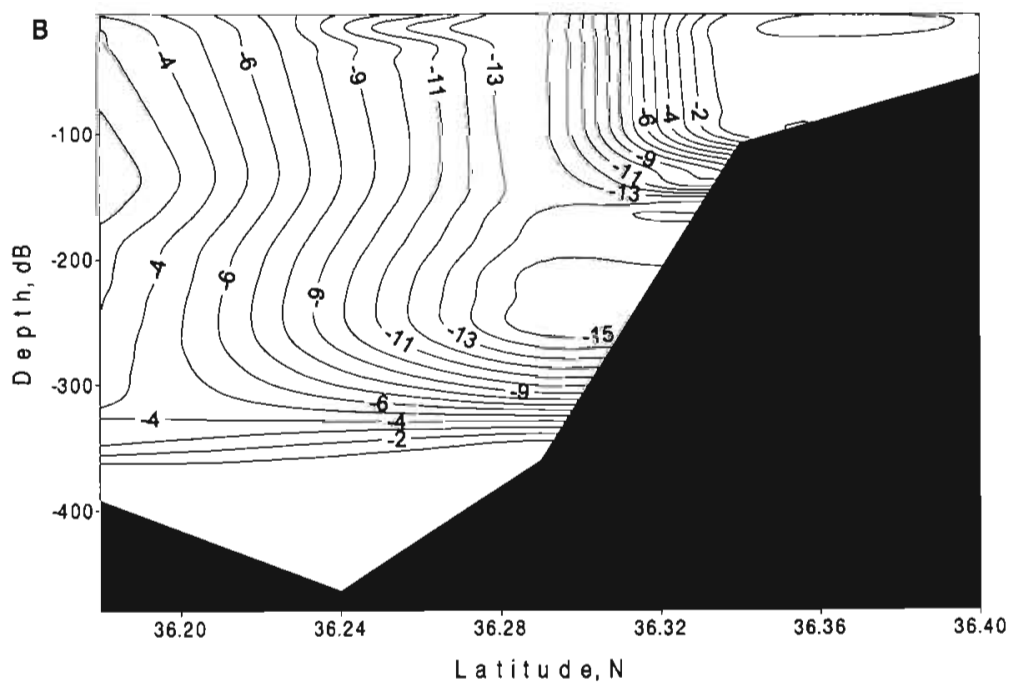

Fig. 4. Cross-slope distribution of (A) Brunt-Väisälä frequencies (c $\mathrm{h}^{-1}$ ) and (B) computed geostrophic velocities $\left(\mathrm{cm} \mathrm{s}^{-1}\right)$ along the section at the traverse of Cadiz

ing that the particulate organic material was already partly degraded. However, a contribution of terrigeneous inputs to the suspended material at these stations cannot be put aside.

In contrast to the POC/PON pattern, the algal pigments (Table 1) presented a homogeneous distribution of chl $a$ in the well-mixed layer $\left(0.30\right.$ to $\left.0.50 \mu \mathrm{g} \mathrm{l}^{-1}\right)$ while phaeopigments (hereafter phaeo), the degraded forms of chlorophyll, decreased from Stn 1 to Stn 5 (1.12 to $0.07 \mu^{-1} \mathrm{~g}^{-1}$ ). In particular, Stn 1 exhibited high phaeo concentrations (up to $0.95 \mathrm{\mu g} \mathrm{l}^{-1}$, on average) and a high phaeo/chl a ratio $(\geq 1.6)$, indicating that in addition to river inputs, phytodetritus contributed to the suspended material in the shelf waters. Using the St. 1

phaeo/chl a ratio as an indicator of inputs of material from the shelf to the stations along the transect, we observed that such material was concentrated at the depths of DOC accumulation (Fig. 3), i.e. at $\operatorname{Stn} 3$ within the undercurrent $(250 \mathrm{~m}$; DOC $=65 \mu \mathrm{M} \mathrm{C}$ ) and at the upper limit of the shallow core of Mediterranean outflow $352 \mathrm{~m}$ (DOC = $58 \mu \mathrm{M} \mathrm{C})$ and at $\operatorname{Stn} 4(382 \mathrm{~m} ; 57 \mu \mathrm{M} \mathrm{C})$ within a layer characterised by maximal Brunt-Väisälä frequency (3.5 $\mathrm{c} \mathrm{h}^{-1}$, Fig. 3). Interestingly, such a high phaeo/chl a ratio (with nevertheless lower phaeo and DOC concentrations) was also observed at Stn 5 $(333 \mathrm{~m})$. Such observations suggest that DOC distribution at the traverse of the Gulf of Cadiz was partly controlled by outputs of degraded particles transported within along-slope descending shelf waters and also by features of the circulation in the Gulf of Cadiz.

Estimation of DOC transport within the Mediterranean outflow: Finally, estimates of the organic carbon transport within the shallow core of Mediterranean outflow throughout this section were made. The computation of geostrophic currents has several limitations, one of which is the difficulty in estimating the velocity of nearbottom water bodies. Although the literature offers a large range of data to estimate the velocity of the Mediterranean waters flowing out of the Strait, there are no values for the shallow core in the Gulf of Cadiz. For instance, the Mediterranean outflow velocity was estimated to be $180 \mathrm{~cm} \mathrm{~s}^{-1}$ on leaving the Gibraltar Strait by Ambar \& Howe $(1979 \mathrm{~b})$, to be $10 \mathrm{~cm} \mathrm{~s}^{-1}$ between 600 and $1500 \mathrm{~m}$ depth along the west coast of Portugal (Madelaine 1967) and to be $20 \mathrm{~cm}$ $\mathrm{s}^{-1}$ for the upper core $(800$ to $1000 \mathrm{~m}$ ) of Mediterranean outflow at the traverse of Cadiz by Ambar \& Howe (1979b). Hence, the range 10 to $20 \mathrm{~cm}$ $\mathrm{s}^{-1}$ most likely represents the shallow core velocity in this area.

From the triangle delimited by bottom contours we estimated the shallow core area to $25800 \mathrm{~m}^{2}$ with an average DOC value of $52 \mu \mathrm{M} \mathrm{C}$. Thus, the DOC flux could range from 1.34 to $2.68 \times 10^{2} \mathrm{~mol} \mathrm{C} \mathrm{s}^{-1}$. For comparison, the average estimates of organic carbon outflow through the Strait of Gibraltar were estimated to ca $5.27 \times 10^{4} \mathrm{~mol} \mathrm{C} \mathrm{s}^{-1}$ in June and $4.94 \times 10^{4} \mathrm{~mol} \mathrm{C} \mathrm{s}{ }^{-1}$ in September (Anonymous 1998) by using an average water transports reported by Bray et al. (1995). Assuming that the shallow core represents only a small 
component of the Mediterranean outflow, it is not surprising to find such low values for organic carbon transports within this water mass. Notwithstanding, because such transport is important in terms of DOC of phytodetritus origin and presumably includes potentially important geochemical markers of the Gulf of Cadiz Shelf, it should be considered when studying the biogeochemistry and the dynamics of the shallow core of Mediterranean outflow along the Iberian coast.

Acknowledgements. We thank the crew of the RV 'Cornide de Saavedra' for their co-operation at sea. Our thanks to $\mathrm{M}$. Tsimplits and S. Bacon for help with calculation of physical properties and A. Bianchi for helpful comments on a draft manuscript. Our special thanks also go to J. H. Sharp, who kindly provided the Deep Pacific and carbon-free water reference standards and P. Wangersky for English correction of the manuscript. This research was funded by the European Commission, MAST III Programme (Contract MAS3 - CT96 0060). Financial support for E. Dafner came from Ministère des Affaires étrangères français and Conseil général des Bouches du Rhône, France.

\section{LITERATURE CITED}

Ambar I (1983) A shallow core of Mediterranean water off western Portugal. Deep-Sea Res 30(6A):677-680

Ambar I, Howe MR (1979a) Observation of the Mediterranean outflow-I. Mixing in the Mediterranean outflow. Deep-Sea Res 26A:535-554

Ambar I, Howe MR (1979b) Observation of the Mediterranean outflow - II. The deep circulation in the vicinity of the Gulf of Cadiz. Deep-Sea Res 26A:555-568

Ambar I, Howe MR, Abdullan MI (1976) A physical and chemical description of the Mediterranean outflow in the Gulf of Cadiz. Dtsch Hydrogr Z 29:58-68

Anonymous (1998) Mid-term scientific report). In: Parrilla G (ed) CANIGO-MAS3-CT96-0060, March 1998. Inst Esp Oceanogr Madrid, p 234-239

Bray NA, Ochoa J, Kinder TN (1995) The role of the interface in exchange through the Strait of Gibraltar. J Geophys Res 100(C6): 10755-10776

Buscail R, Pocklington R, Daumas R, Guidi L (1990) Fluxes and budget of organic matter in the benthic boundary layer over the north-western Mediterranean margin. Cont Shelf Res 10(9-11):1089-1122

Cano N (1978) Resultados de la campaña 'Alborán-76' Bol Inst Esp Oceanogr 247:3-50

Doval MD, Álvarez-Salgado XA, Pérez F (1997) Dissolved organic matter in a temperate embayment affected by coastal local upwelling. Mar Ecol Prog Ser 157:21-37

Eittreim S, Thorndike E, Suljvan L (1976) Turbidity distribution in the Atlantic Ocean. Deep-Sea Res 23:1115-1127

Greze VN, Kovalev AV, Baldina EP, Bileva OK, Shmeleva AA (1985) Zooplankton transfer through the Gibraltar Strait and peculiarities of its taxonomic composition and distribution in adjacent areas. Invest Pesq 49\{1\}:3-13

Käse RH, Zenk W (1996) Structure of the Mediterranean

Editorial responsibility: Otto Kinne (Editor).

Oldendort/Luhe, Germany water and Meddy characteristics in the north-eastern Atlantic. In: Krauss W (ed) The warmwater sphere of the North Atlantic Ocean. Gebrüder Bornträger, Berlin, p 369

Madelaine F (1967) Calculs dynamiques au large de la Peninsula Iberique. Cah Océanogr 19:181-194

Madelaine F (1970) Influence de la topographie du fond sur l'écoulement Mediterranéen entre le détroit de Gibraltar et le Cap Saint-Vincent. Cah Océanogr 22:43-61

Milliman JD (1994) Organic matter carbon in US Atlantic continental slope sediments: decoupling the grain-size factor. Deep-Sea Res II 41(4-6):797-808

Minas HJ, Minas M. (1993) Influence du détroit de Gibraltar sur la biogéochimie de la Méditerranée et du proche Atlantique. Annal Inst Océanogr 69(1):203-214

Morley N, Burton JD, Tankere SPC, Martin JM (1997) Distribution and behaviour of some dissolved trace metals in the western Mediterranean Sea. Deep-Sea Res 44(3-4):675-691

Ogawa H, Ogura N (1992) Comparison of two methods for measuring dissolved organic carbon in seawater. Nature (Lond) 356:696-698

Parsons TR, Takahashi T, Hargrave B (1977) Biological oceanographic processes. Pergamon Press, Oxford

Rubin JP, Cano P, Arrate J, Lafuente JG., Escanez J, Vargas M. Alonsa JC, Hernandez F (1997) El ictioplankton, el mesozooplankton y la hidrologia en el Golfo de Cadiz, estrecho de Gibraltar y sector noroeste del mar Alboran, en julio de 1994. Inf Tec Inst Esp Oceanogr 167:44

Sempéré R, Cauwet G (1995) Occurrence of organic colloids in the stratified estuary of the Krka River (Croatia). Estuar Coast Shelf Sci 40:105-114

Sempéré R, Cauwet G, Randon J (1994) Ultrafiltration of seawater with a zirconium and aluminum oxide tubular membrane: application to the study of colloidal organic carbon distribution in an estuarine bottom nepheloid layer. Mar Chem 46:49-60

Smith DC, Simon M, Alldredge A, Azam F (1992) Intense hydrolytic enzyme activity on marine aggregates and umplication for rapid particle dissolution. Nature (Lond) 359:139-141

Stanton BR (1983) Low frequency variability in the Mediterranean Outflow west of Gibraltar. Deep-Sea Res 30(7A):743-761

UNESCO (1994) Protocols for Joint Global Ocean Flux Study (JGOFS) core measurements. Man Guides 29:1-170

Van Geen A, Rosener P, Boyle E (1988) Entrainment of tracemetal-enriched Atlantic-shelf water in the inflow to the Mediterranean Sea. Nature (Lond) 331:423-426

Van Geen A. Boyle E, Moore WS (1991) Trace metals enrichments in waters of Gulf of Cadiz, Spain. Geochim Cosmochim Acta 55:2173-2191

Walsh JJ (1991) Importance of continental margins in the marine biogeochemical cycling of carbon and nitrogen. Nature (Lond) 350:53-55

Yoro SC, Sempéré R, Turley C, Unanue MA, Durrieu De Madron X, Bianchi M (1997) Cross-slope variations of organic carbon and bacteria in the Gulf of Lion in relation to water dynamics (north-western Mediterranean). Mar Ecol Prog Ser 161:255-264

Zenk W (1975) Some current and temperature observations in the Mediterranean outflow west of Gibraltar. Meteor ForschErgeb A 15:20-48

Submitted: January 4, 1999; Accepted: August 17, 1999

Proofs received from author(s): October 29, 1999 